\title{
Towards the First Total Synthesis and Anticancer Screening of Polycarponin C: A Cyclic Octapeptide
}

\author{
NIRMALA V. SHINDE ${ }^{1 *}$, AVINASH S. DHAKE ${ }^{2}$ and KISHAN P. HAVAL ${ }^{3}$ \\ 'Department of Pharmaceutical Sciences, Jawaharlal Nehru Technological University, \\ Kakinada, Andhra Pradesh, India. \\ 2Department of Pharmaceutical Chemistry, S.M.B.T. College of Pharmacy, Nandi Hills, \\ Dhamangaon. Tah: Igatpuri, Dist: Nashik (MH) India. \\ ${ }^{3}$ Department of Chemistry, Dr. Babasaheb Ambedkar Marathwada University, \\ SubcentreOsmanabad(MH) India. \\ ${ }^{*}$ Corrosponding author E-mail:nirmalampharm @ rediffmail.com \\ http://dx.doi.org/10.13005/ojc/320159
}

(Received: November 23, 2015; Accepted: March 11, 2016)

\begin{abstract}
The present study describes designing, synthesis and anticancer screening of a proline rich cyclic octapeptide polycarponin $\mathrm{C}$, by solution phase synthesis. The synthesis was carried out by coupling a tetrapeptide Boc-Pro-Thr-Leu-Pro-OH with another tetrapeptide Boc-Pro-Val-Leu-Phe$\mathrm{OH}$, followed by cyclization of the linear octapeptide. The structure of the synthesized compound was then confirmed by spectral analysis. From the results of biological activity, it was concluded that the compound has shown moderate activity against SR human tumor cell lines of Leukemia when compared with Vincristine as a standard.
\end{abstract}

Key words:Cyclic Peptide, Solution phase synthesis, p-nitro phenyl ester Method, Coupling Agent, Anticancer.

\section{INTRODUCTION}

Anticancer drug development from natural sources has always been fascinating and interesting for researchers working in the field of medicinal chemistry and drug development. Owing to the various biological activities like antimicrobial, cytotoxic, anti-HIV, anti-inflammatory, serine protease and protein tyrosine phosphatase inhibitory activity possessed by cyclic peptides ${ }^{1-7}$ and to obtain a natural bioactive peptide in good yield, in the present work an attempt has been made towards the first total synthesis of a proline rich cyclic octapeptide polycarponin C, cyclo-( ProThr-Leu-Pro-Pro-Val-Leu-Phe), isolated from whole plants of Polycarpon prostratum, belonging to family Caryophyllaceae ${ }^{8}$. The synthesis was attempted by solution phase technique ${ }^{9}$ followed by cyclization of linear octapeptide by $p$-nitro phenyl ester method ${ }^{12}$. The structure of the synthesized compound was 
confirmed by detailed spectral analysis. The synthesized compound was then subjected for preliminary cytotoxic activity by using Brine shrimp assay, and further followed by screening against 60 human tumor cell lines at $\mathrm{NCI}$, USA. The results of anticancer screening showed that the compound is moderately active against SR human tumor cell lines of Leukemia when compared with Vincristine as a standard.

\section{MATERIALS AND METHODS}

All L-amino acids, di-tertbutyldicarbonate $\left(\mathrm{BOC}_{2} \mathrm{O}\right)$, diisopropylcarbodiimide (DIPC), trifluoroacetic acid (TFA), triethylamine (TEA), pyridine and $\mathrm{N}$-methylmorpholine (NMM) were purchased from Spectrochem Limited (Mumbai, India).Melting points were determined by using digital melting point apparatus.

The IR spectra were run on FTIR spectrophotometer,JASCO 4100 using a thin film supported on $\mathrm{KBr}$ pellets or utilizing chloroform and $\mathrm{NaCl}$ cells. ${ }^{1} \mathrm{H}$ NMR and ${ }^{13} \mathrm{C}$ NMR spectra were recorded on Bruker AC NMR spectrometer using DMSO as a solvent. The mass spectrum of the cyclopeptide was recorded on JMS-DX 303 Mass spectrometer operating at $70 \mathrm{eV}$ by ESIMS/MS.

In order to carry out the total synthesis of cyclicpeptide, polycarponin C, cyclo-(Pro-Thr-LeuPro-Pro-Val-Leu-Phe), it was disconnected into four dipeptide units, BOC-Pro-Thr-OMe 1, Boc-Leu-ProOMe 2, Boc-Pro-Val-OMe 3, Boc-Leu-Phe-OMe 4. The dipeptides were obtained by coupling Boc amino acids with the respective amino acid methyl esters, by using DIPC as a coupling agent. The ester group of dipeptide 1 and 3 was then removed by using $\mathrm{LiOH}$ and the Boc group of dipeptide 2 and 4 was removed by using TFA. The deprotected units were then coupled to get two tetra peptides Boc-Pro-ThrLeu-Pro-OMe 5 and Boc-Pro-Val-Leu-Phe-OMe 6 . The resulting tetrapeptides were then coupled together by using DIPC and chloroform to obtain a linear octapeptide, which was then cyclized by using p-nitro phenyl ester method to get titled compound.

\section{General method for preparation of di/tetra/linear octapeptide}

L-Amino acid methyl ester hydrochloride/ dipeptide methyl ester/tetra peptide methyl ester (10 mmol) was dissolved in chloroform $\left(\mathrm{CCl}_{3}, 20\right.$ $\mathrm{ml})$. To this, TEA $(2.8 \mathrm{ml}, 20 \mathrm{mmol})$ was added at 0 ${ }^{\circ} \mathrm{C}$ and the reaction mixture was stirred for $15 \mathrm{~min}$. Boc-L-amino acid/Bocdipeptide/ Boctetrapeptide (10 $\mathrm{mmol})$ in chloroform $(20 \mathrm{ml})$ and DIPC (10 mmol) were added with stirring. After $24 \mathrm{~h}$, the reaction mixture was filtered and the residue was washed with chloroform $(30 \mathrm{ml})$ and added to the filtrate. The filtrate was was hed with $5 \% \mathrm{NaHCO}_{3}$ and saturated $\mathrm{NaCl}$ solutions. The organic layer was dried over anhydrous $\mathrm{Na}_{2} \mathrm{SO} 4$, filtered and evaporated in vacuum. The crude product was recrystallized from a mixture of chloroform and petroleum ether (b.p. 40$60{ }^{\circ} \mathrm{C}$ ) followed by cooling at $0^{\circ} \mathrm{C}$. By using above procedure, compounds 1-7 were synthesized.

\section{Procedure for cyclization of linear octapeptide $^{12}$ :}

The cyclization of linear octapeptide was attempted by using p-nitrophenyl ester method. The ester group of linear fragment was removed

Table 1: Results for Cytotoxic activity by using Brine Shrimp Assay:

\begin{tabular}{ccccccc}
\hline Compound & $\begin{array}{c}\text { Conc. } \\
\text { (ppm or } \boldsymbol{\mu g} / \mathrm{ml})\end{array}$ & \multicolumn{2}{c}{$\begin{array}{c}\text { Number of Surviving } \\
\text { Napulii After 24 h } \\
\text { T2 }\end{array}$} & T1 & $\begin{array}{c}\text { Total Number } \\
\text { of Survivors }\end{array}$ & $\begin{array}{c}\% \\
\text { M3 }\end{array}$ \\
& 1000 & 4 & 6 & 4 & 14 & 53.33 \\
Poly C & 500 & 5 & 5 & 5 & 15 & 50 \\
& 250 & 5 & 6 & 7 & 18 & 40 \\
& 125 & 7 & 6 & 7 & 20 & 33.33 \\
& 62.5 & 8 & 9 & 8 & 25 & 16.66 \\
\end{tabular}

\footnotetext{
${ }^{*} \mathrm{~T}=$ Trial $\quad \mathrm{LC} 50=460.9 \mu \mathrm{g} / \mathrm{ml}$
} 
with $\mathrm{LiOH}$ and the p-nitrophenyl ester group was introduced. For introduction of p-nitro phenyl ester group, the Boc-peptide carboxylic acid(1.5 mmol) was dissolved in chloroform $(15 \mathrm{ml})$ at $0{ }^{\circ} \mathrm{C}$, to which p-nitrophenyl $(0.27 \mathrm{gm}, 2 \mathrm{mmol})$ was added, and stirred for 12 hrs at RT. The reaction mixture was filtered and the filtrate was washed with $\mathrm{NaHCO}_{3}$ solution (10\%) until excess of p-nitrophenyl was removed and finally washed with $5 \% \mathrm{HCl}(5 \mathrm{ml})$ to get Boc-peptide-pnp ester.

To the above Boc-peptide-pnp-ester (1.2 mmol) in $\mathrm{CHCl}_{3}(15 \mathrm{ml}), \mathrm{CF}_{3} \mathrm{COOH}(0.274 \mathrm{~g}$,
$2.4 \mathrm{mmol}$ ) was added, stirred for 1 hour at room temperature and washed with $10 \% \mathrm{NaHCO}_{3}$ solution. The organic layer was dried over anhydrous $\mathrm{Na}_{2} \mathrm{SO}_{4}$. To the Boc-deprotected peptide-pnp-ester in $\mathrm{CHCl}_{3}$ (15ml), N-methyl morpholine (1.4ml, 2mmol.) was added and kept at $0^{\circ} \mathrm{C}$ for 7 days. The reaction mixture was washed with $10 \% \mathrm{NaHCO}_{3}$ until the byproduct $\mathrm{p}$-nitrophenyl was removed completely and finally washed with $5 \% \mathrm{HCl}(5 \mathrm{ml})$. The organic layer was dried over anhydrous $\mathrm{Na}_{2} \mathrm{SO}_{4}$. Chloroform and pyridine were distilled off to get the crude cyclized compound, which was recrystallized from $\mathrm{CHCl}_{3} / \mathrm{n}$-hexane.
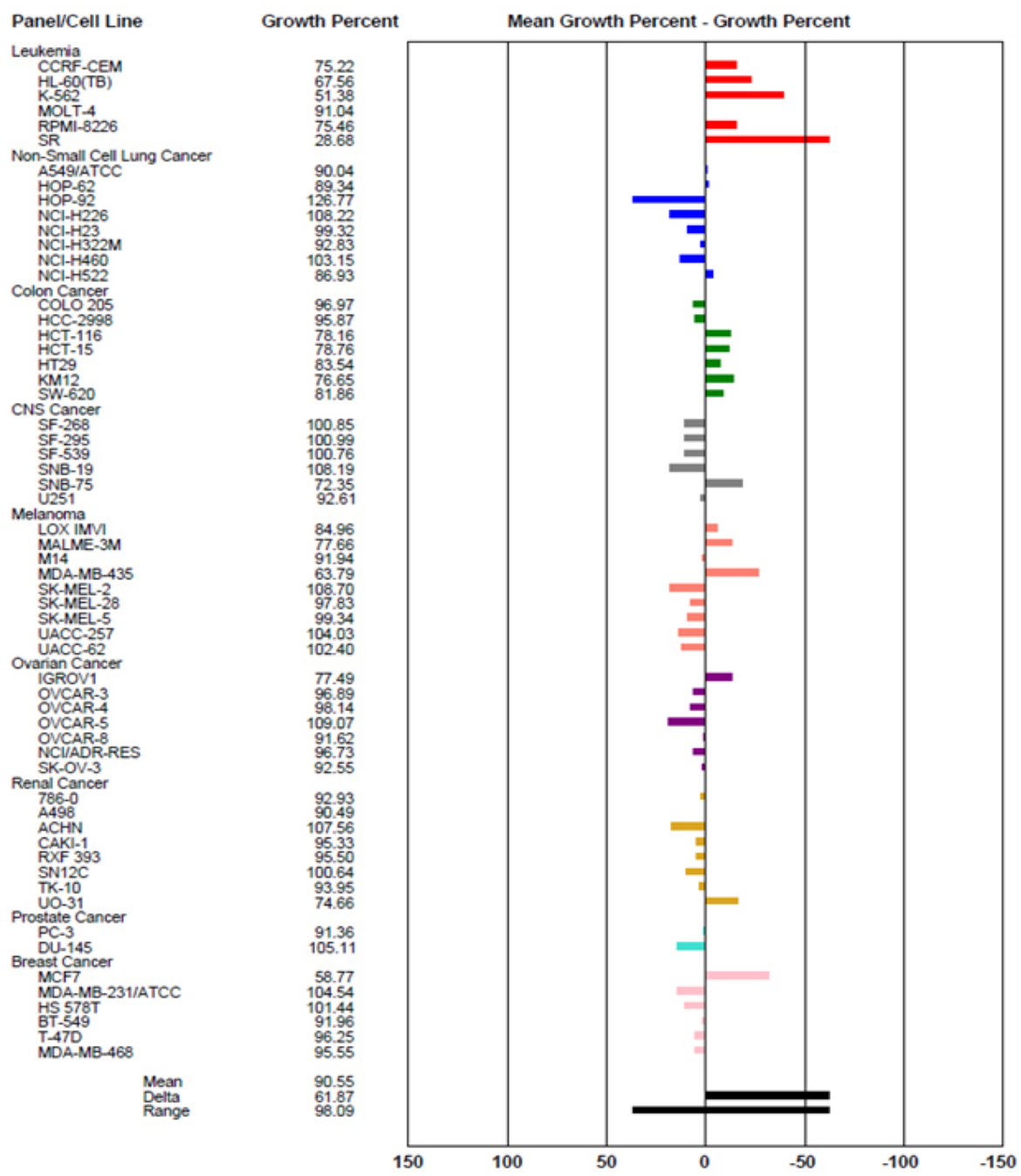

Graph 1: DTP One dose Mean graph for Polycarponin C 
Anticancer activity of synthesized compound Preliminary cytotoxic activity by Brine Shrimp Lethality Assay (BSLA) ${ }^{10,11}$

Brine shrimp eggs were obtained from the aquarium shop, Nasik. Artificial sea water was prepared from $(1 \% \mathrm{NaCl})$ nitrate, phosphate, and silicate-free sea-salt and distilled water $(35 \mathrm{~g} / \mathrm{l})$ at $25^{\circ} \mathrm{C}$ under constant illumination. The saltwater solution was aerated continuously during incubation with an aquarium air pump. The seawater was put in a small plastic container (hatching chamber) with a partition for dark (covered) and light areas. Shrimp eggs were added into the dark side of the chamber while the lamp above the other side (light) will attract the hatched shrimp. Two days were allowed for the shrimp to hatch and mature as nauplii (larva). After

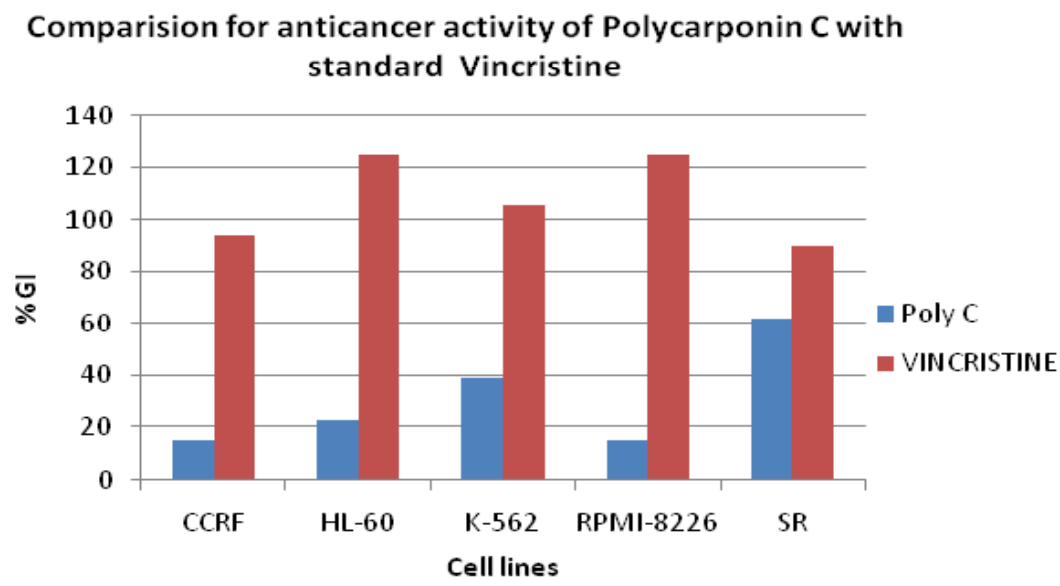

Graph. 2: Comparison of synthesized Polycarponin C for anticancer screening with data of vincristine against leukemia human tumor cell lines.

Table 2: \%Gl shown by Polycarponin C against different human tumor cell lines

\begin{tabular}{|c|c|c|c|}
\hline $\begin{array}{l}\text { Human Tumor } \\
\text { Cell Line }\end{array}$ & $\begin{array}{l}\% \text { GI for } \\
\text { comp. VIII }\end{array}$ & $\begin{array}{l}\text { Human Tumor } \\
\text { Cell Line }\end{array}$ & $\begin{array}{l}\% \text { GI for } \\
\text { comp. VIII }\end{array}$ \\
\hline Leukemia & & Ovarian Cancer & \\
\hline CCRF-CEM & 15.33 & IGROV1 & 13.6 \\
\hline HL-60(TB) & 22.99 & & \\
\hline K-562 & 39.17 & & \\
\hline RPMI-8226 & 15.09 & & \\
\hline SR & 61.87 & & \\
\hline Colon cancer & & Renal Cancer & \\
\hline HCT-116 & 12.39 & UO-31 & 15.89 \\
\hline HCT-15 & 11.79 & & \\
\hline HT29 & 7.01 & & \\
\hline KM12 & 13.9 & & \\
\hline SW-620 & 8.69 & & \\
\hline CNS Cancer & & Breast Cancer & \\
\hline SNB-75 & 18.20 & MCF7 & 31.78 \\
\hline Melanoma & & Mean & 90.55 \\
\hline LOX IMVI & 5.59 & Delta & 61.87 \\
\hline MALME-3 & 12.89 & ange & 98.09 \\
\hline MDA-MB-435 & 26.76 & & \\
\hline
\end{tabular}


two days, when the shrimp larvae are ready, $4 \mathrm{ml}$ of the artificial seawater was added to each test tube containing different conc. of drug and 10 brine shrimps were introduced into each tube. Thus, there were a total of 30 shrimps per dilution. Then the volume was adjusted with artificial seawater up to $5 \mathrm{ml}$ per test tube. The test tubes were left uncovered under the lamp. The number of surviving shrimps were counted and recorded after 24 hours. The lethality concentration $\left(\mathrm{LC}_{50}\right)$ was assessed at $95 \%$ confidence intervals. The percentage mortality
$(\% \mathrm{M})$ was also calculated by dividing the number of dead nauplii by the total number, and then multiplied by $100 \%$. This is to ensure that the death (mortality) of the nauplii is attributed to the activity of the compound. The results of activity are shown in Table 1.

\section{In vitro cytotoxic activity against Human tumor cell lines ${ }^{12}$}

The synthesized compoun dwas screened for in vitro anticancer assay by National Cancer

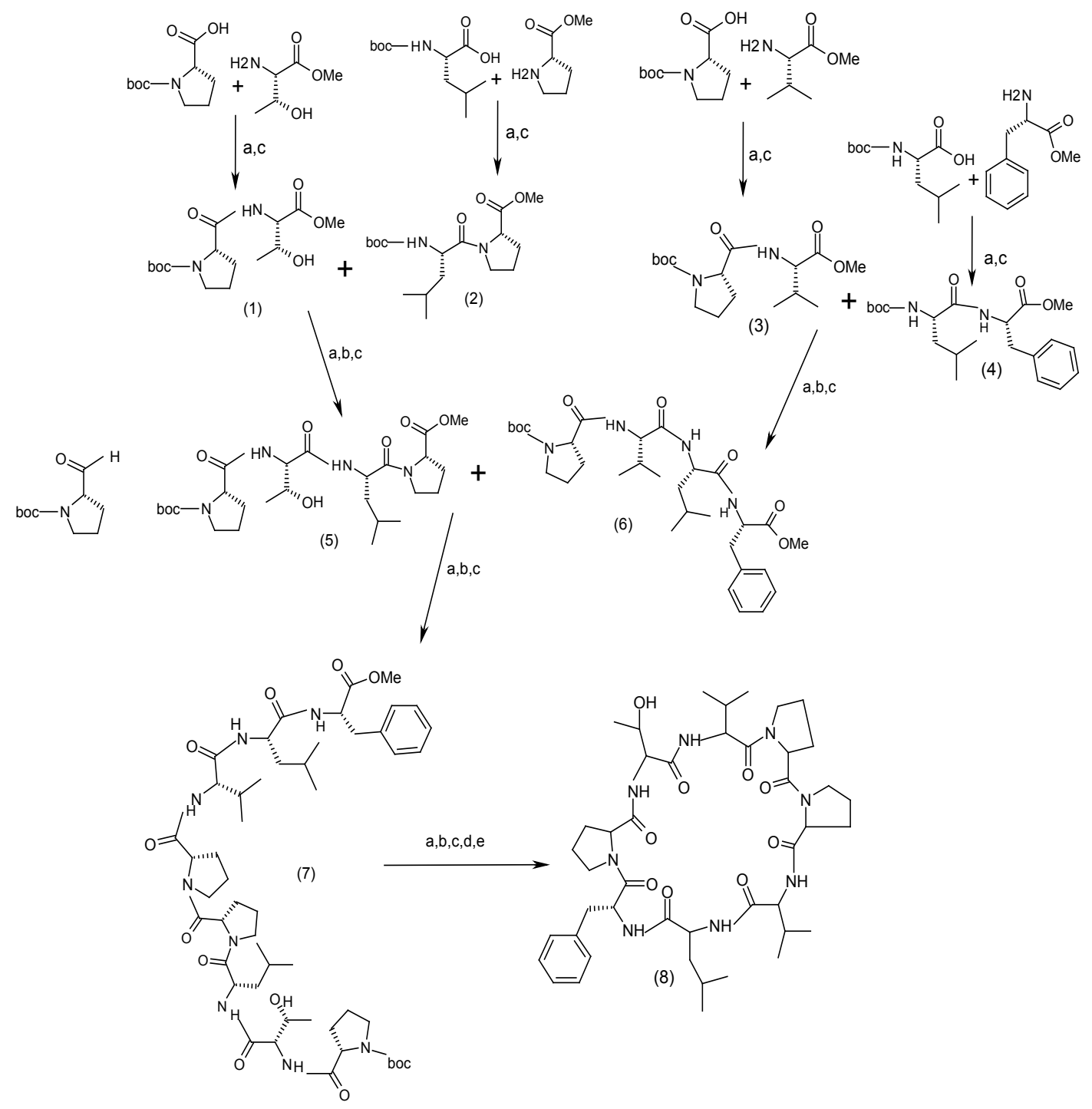

Where: $a=$ DIPC, NMM, CHCl3, RT, 24h, b= TFA, NMM,RT,1h, $\mathrm{c}=\mathrm{LiOH}, \mathrm{THF}: \mathrm{H} 2 \mathrm{O}(1: 1)$, reflux, $15 \mathrm{mins} \mathrm{d}=$ pnp-, $\mathrm{CHCl} 3, \mathrm{RT}, 12 \mathrm{~h}, \mathrm{e}=\mathrm{NMM}, \mathrm{CHCl} 3,0^{\circ} \mathrm{C}, 7$ days

Scheme 1: Synthetic route for Polycarponin C 
Institute (NCl), Bethesda, USA in a panel of 60 human tumor cell lines. The screening of the compound operated with In Vitro Cell Line Screening Project (IVCLSP), which is dedicated service, providing direct support to the DTP anticancer drug discovery program. The screening was carried out against 60 different human tumor cell lines of the leukemia, Non-smallcell lung, colon, CNS, melanoma, ovarian, renal, Prostrate and breast cancers which was aimed in showing selective growth inhibition or cell killing of particular tumor cell lines by specific compound. The screening begins with the evaluation of selected compounds at asingle dose of $10^{-5} \mathrm{M}$. The output from the single dose screen is reported as a mean graph and is available for analysis by the compare program. The result of anticancer screening is shown in fig. 1 and Table 2.

\section{RESULTS AND DISCUSSION}

\section{Spectral characterization \\ Physical state: Semisolid mass}

IR data: intense $\mathrm{C}=\mathrm{O}$ absorptions at 3300 and $1650 \mathrm{~cm}^{-1}$. absorptions at $3427,1650 \mathrm{~cm}^{-1}, 1650$ $\mathrm{cm}^{-1}$ are due to amino and amide carbonyl groups respectively FABMS showed $\mathrm{M}^{+}$ion peak at $\mathrm{m} / \mathrm{z}$ 860.

\section{C NMR: showed six amide carbonyl carbon}

$\delta 171$ for $\mathrm{C}=\mathrm{O}$ of Thr, $\delta 62.5$ for $\mathrm{C} \alpha$ of Thr, $\delta$ 66.5 for $\mathrm{C} \beta$ of Thr, $\delta 22$ for $\mathrm{C} \lambda$ of Thr, $\delta 172$ for $\mathrm{C}=\mathrm{O}$ of Phe, $\delta 52.9$ for $\mathrm{C} \alpha$ of Phe, $\delta 38$ for $\mathrm{C} \beta$ of Phe, $\delta$ 171.5 for $\mathrm{C}=\mathrm{O}$ of Val, $\delta 62$ for $\mathrm{C} \alpha$ of Val, $\delta 31.5$ for $\mathrm{C} \beta$ of Val, $\delta 19$ for $\mathrm{C} \lambda$ of $\mathrm{Val}, \delta 170.5$ for $\mathrm{C}=\mathrm{O}$ of Leu, $\alpha 50$ for C $\alpha$ of Leu, $\delta 41.5$ for C $\delta$ of Leu, $\delta 25.1$ for Cã of Leu, $\delta 172.5$ for $\mathrm{C}=\mathrm{O}$ of $\mathrm{Leu}_{2}, \delta 51$ for $\mathrm{C} \beta$ of $\mathrm{Leu}_{2}, \delta 43.5$ for $\mathrm{C} \beta$ of $\mathrm{Leu}_{2}, \delta 25$ for Cy of $\mathrm{Leu}_{2}, \delta$ 173 for $\mathrm{C}=\mathrm{O}$ of $\mathrm{Pro}_{1}, \delta 62.2$ for $\mathrm{C} \alpha$ of $\mathrm{Pro}_{1}, \delta 32.2$ for $\mathrm{C} Y$ of $\mathrm{Pro}_{1}, \delta 22.2$ for $\mathrm{C} \gamma$ of $\mathrm{Pro}_{1}, \delta 171$ for $\mathrm{C}=\mathrm{O}$ of $\mathrm{Pro}_{2}, \delta 61.2$ for Cá of $\mathrm{PrO}_{2}, \delta 31$ for $\mathrm{C} \beta$ of $\mathrm{Pro}_{2}, \delta 22$ for $\mathrm{C} \gamma$ of $\mathrm{Pro}_{2}$, ä 170.8 for $\mathrm{C}=\mathrm{O}$ of $\mathrm{PrO}_{3}, \delta 59.2$ for $\mathrm{C} \delta$ of $\mathrm{Pro}_{3}, \delta 28.6$ for $\mathrm{C} \alpha$ of $\mathrm{Pro}_{3}, \delta 25.8$ for $\mathrm{C} \gamma$ of $\mathrm{PrO}_{3}$

\section{H NMR: showed five amide $\mathrm{N}-\mathrm{H}$ signals}

$\delta 7.2$ for $\mathrm{H}_{\mathrm{N}}$ of Thr, $\delta 4.55$ for $\mathrm{H}_{\mathrm{N}}$ of Thr, $\delta$ 4.65 for $\mathrm{H} \beta$ of Thr, $\delta 1.36$ for $\mathrm{H} \beta$ of Thr, $\delta 11.04 \beta$ for $\mathrm{H}_{\mathrm{N}}$ of Phe, $\delta 5.02$ for $\mathrm{H} \alpha$ of Phe, $\delta 3.01$ for $\mathrm{H} \beta$ of Phe, $\delta 8.7$ for $\mathrm{H}_{\mathrm{N}}$ of Val, $\delta 4.7$ for $\mathrm{H} \alpha$ of Val, $\delta$ 2.5 for $\mathrm{H} \beta$ of Val, $\delta 1.5$ for $\mathrm{H} \beta$ of Val, $\delta 8$ for $\mathrm{H}_{\mathrm{N}}$ of $\mathrm{Leu}_{1}, \delta 5.36$ for $\mathrm{H} \alpha$ of $\mathrm{Leu}_{1}, \delta 1.74$ for $\mathrm{H} \beta$ of $\mathrm{Leu}_{1}, \delta$ 1.90 for $\mathrm{H} \beta$ of $\mathrm{Leu}_{1}, \delta 8.5$ for $\mathrm{H}_{\mathrm{N}}$ of $\mathrm{Leu}_{2}, \delta 5.05$ for $\mathrm{H} \alpha$ of $\mathrm{Leu}_{2}, \delta 1.7$ for $\mathrm{H} \beta$ of $\mathrm{Leu}_{2}, \delta 1.94$ for $\mathrm{H} \beta$ of $\mathrm{Leu}_{2}, \delta 4.45$ for $\mathrm{H} \alpha$ of $\mathrm{PrO}_{1}, \delta 2.16$ for $\mathrm{H} \beta$ of $\mathrm{Pro}_{1}$, $\delta 1.8$ for $\mathrm{H} \beta$ of $\mathrm{Pro}_{1}, \delta 4.4$ for $\mathrm{H} \alpha$ of $\mathrm{PrO}_{2}, \delta 1.90$ for $\mathrm{H} \beta$ of $\mathrm{PrO}_{2}, \delta 1.65$ for $\mathrm{H} \beta$ of $\mathrm{Pro}_{2}, \delta 4.39$ for $\mathrm{H} \alpha$ of $\mathrm{Pro}_{3}, \delta 1.90$ for $\mathrm{H} \beta$ of $\mathrm{Pro}_{3}, \delta 2.16$ for $\mathrm{H} \beta$ of $\mathrm{Pro}_{3}$, 4.08 for $\mathrm{H} \delta$ of $\mathrm{Pro}_{3}$ Elemental analysis: $\mathrm{C}=63.96$, $\mathrm{H}=8.4, \mathrm{~N}=13.10, \mathrm{O}=14.91$

\section{CONCLUSION}

The compound was synthesized with good yield by using solution phase technique. It showed moderate activity against SR human tumor cell lines of Leukemia when compared with Vincristine as a standard. In consultation with literature survey, synthesis of analogs of this molecule may lead to the development of potent anticancer agents.

\section{ACKNOWLEDGEMENT}

Authors are thankful to CSIR, LucknowCDRI, New Delhi for financial assistance. We also extend our thanks to S.M.B.T. College of Pharmacy, Dhamangaon, Nashik for providing necessary facilities to do the research work and SAIF, Chandigarh for spectral analysis. Authors are also thankful to $\mathrm{NCI}$, USA for carrying out anticancer activity.

\section{REFERENCES}

1. Shinde,N.V.;Himaja, M.;Bhosale, S.K.;Ramana, M.V.;Sakarkar, D.M. Indian J Pharm Sci.2008, 70(6), 695-852

2. Dahiya R.;Gautam H. Bulletin Pharm. Res.2011,1(1), 1-10

3. Chaudhary S.; Kumar H.;Verma H.;Rajpoot
A. Int J. PharmTech Res.2012,4(1), 194-200

4. Kawagishi H.; Somoto A.;Kuranari J.; Kimura A.; Chiba S. Tetrahedron1993,34(21), 34393440

5. Chaudhary S.;Kumar H.;Verma H.;Rajpoot A. Int Journal of PharmTech Res.2012, 4(1), 
194-200

6. Hernández D. Eur. J. Org. Chem.2008, 3389-3396

7. Shinde N.V.;Himaja M.;Bhosale S.K.;Ramana M.V.;Sakarkar D.M. Asian J Chem.2010,22(2), 996-1000

8. Ding, Z.T.; Zhou, J.;Tan, N.; Cheng, Y.; Deng, S. ActabotanicaSinica.2001, 43(5), 541-44
9. Bodanszky M. and Bodanszky A., Practice of peptide synthesis;Springer-verlog Publishers. New York, (1984)

10. Bussmann R.;Malca G.; Glenn A. J. Ethnopharmacology.2011, 137, 121-140

11. Houghton P.; Fang R.;Techatanawat I. Science Direct.2007,42, 377-387.

www.nci.gov.in 